\title{
New blattarians and a review of dictyopteran assemblages from the Lower Cretaceous of Mongolia
}

\author{
Peter Vršanský \\ Acta Palaeontologica Polonica 53 (1), 2008: 129-136 doi:http://dx.doi.org/10.4202/app.2008.0109
}

Dictyopteran assemblages (cockroaches, mantises and termites) from Mongolia were uniform, being composed of the same genera throughout the Early Cretaceous (more than 30 million years), corresponding to the 'dry and warm Baissa type' assemblages from Siberia. The assemblage from Shin-Khuduk is exceptional, consisting of a single identifiable blattulid species, Vrtula sama gen. et sp. nov. Assemblages from Eastern Erdenyi-Ula, Khurilt, Kholbotu-Gol, and Shar-Tologoy are composed of species already known from the richest Lower Cretaceous locality Bon Tsagaan, but species representation in the various assemblages differs considerably. Nuurcala srneci sp. nov. from Khurilt Bed 210/24, with a forewing length under $12 \mathrm{~mm}$, is the smallest and best-studied example of the cosmopolitan Mesozoic family Caloblattinidae. The last occurrence of the predominantly Palaeozoic family Phyloblattidae is reported from Bon Tsagaan.

Key words: Blattaria, Mantodea, Isoptera, cockroaches, Cretaceous, Mongolia.

Peter Vršanský geolvrsa@ savba.sk, Arthropoda Laboratory, Paleontological Institute, Russian Academy of Sciences, Profsoyuznaya 123, 117868 Moscow, Russia; present address: Geological Institute, Slovak Academy of Sciences, Dúbravská cesta 9, P.O. BOX 106, 84005 Bratislava 45, Slovakia.

This is an open-access article distributed under the terms of the Creative Commons Attribution License (for details please see creativecommons.org), which permits unrestricted use, distribution, and reproduction in any medium, provided the original author and source are credited. 